\title{
Polish Anglicisms in the fields of leisure, fashion and entertainment against historical background
}

\author{
Alicja Witalisz ${ }^{1}$ \\ Pedagogical University of Krakow
}

\begin{abstract}
Domain-specific loans mirror historical and cultural changes in specific areas of life and allow to identify the language which at a certain point in time is considered most prestigious by the recipient language users. Foreign loans are always evidence of cultural contacts of the recipient language speech community with other communities, and reflect the sharing of social, economic, political and cultural phenomena among various nations. The article offers a historical overview of Polish domain-specific Anglicisms and presents and analyses over a thousand English loans of four different types in the areas of leisure, fashion and entertainment, which have been enriching Polish since the $17^{\text {th }}$ century.
\end{abstract}

Keywords: borrowing, Anglicism, cultural loans, domain-specific loans, English-Polish language contact.

Every speech-community learns from its neighbours. Objects, both natural and manufactured, pass from one community to the other, and so do patterns of action, such as technical procedures, warlike practices, religious rites, or fashions of individual contact. (Leonard Bloomfield, 1933, p. 445)

1 Corresponding author: Katedra Językoznawstwa Angielskiego, Instytut Neofilologii, ul. Karmelicka 41, p. 305, 31-128, Krakow, Poland.

Email: alicja.witalisz@up.krakow.pl 


\section{Introduction}

Even though Poland cannot be said to neighbour any of the English-speaking countries, English linguistic influence on Polish has been significant. Lexical Anglicisms have been present in this Slavic language since the $17^{\text {th }}$ century, yet it was only the second half of the $20^{\text {th }}$ century that witnessed a steady and continuous increase in Anglicisms. The infrequent $18^{\text {th }}$ - and $19^{\text {th }}$-century Anglicisms enriched chiefly the semantic fields of maritime navigation, sports, social life and food and drink, whereas the multiple $21^{\text {st }}$-century English loans occupy the territory of IT technology and cybernetics.

Recent research by Jacek Fisiak and his team (SZA F) estimates the number of English lexical loans in Polish at ca. 7,000 lexemes (3.2\% of the Polish lexical stock), which means that their number has tripled in the last 25 years (cf. SZA M-W). While pre1989 English loans were chiefly loanwords (Fisiak, 1961; Mańczak-Wohlfeld, 1992, 1995, 2006, 2010), the last three decades have abounded in other types of loans from English, such as loan translations, loanblends, as well as semantic, morphological, pragmatic and structural loans (Otwinowska-Kasztelaniec, 2000; Witalisz, 2007a, 2015, 2016; Zabawa, 2012). The total number of various types of Anglicisms in contemporary Polish has been estimated at ca. 3.7\% of the Polish lexicon (Witalisz, 2016, p. 169). It must be emphasised though that English loans are also present in professional jargons (e.g. IT technology, economics, medicine), in the slang language of the youth, as well as in the languages of various subcultures such as for instance rap singers, fandom members, video game players, drug addicts etc., hence the quoted percentage may be underestimated.

Anglicisms and the semantic fields they enrich in Polish have been fairly well researched, with the earliest comprehensive studies going back to Koneczna (19361937), who registers over five hundred lexical loans in Standard Polish, and Doroszewski (1938, p. 79), whose work analyses English loanwords in the language of the Polish diaspora in the USA. While the present study is devoted to the influence of English on Standard Polish spoken in Poland, our attention will focus on various types of Anglicisms within the following semantic fields:

1) ENTERTAINMENT, including the following subfields: music, cinema \& theatre,

1. TV \& radio, culture \& art, books \& press;

2) LEISURE, including sports, travelling, dances, games, beautifying treatments,

2. free time \& lifestyle, food \& drink, drugs, and

3) FASHION, including clothes, types of cloth \& shoes, and others (hairstyles, colours, accessories). 
The specific subfields within each domain reflect the thematic types of English loans that have been excerpted in a systematic research from various lexicographic resources as well as from my students' seminar papers and my own collection carried out systematically over the last decade (see Section 3). The collected data (see Appendix 1) will be classified with respect to the semantic fields in question and the type of a borrowed element, which will form the basis for a detailed linguistic analysis in Section 3.

One other focus of the article is the inseparable relation between the history of a nation and its language, reflected, among others, through linguistic borrowing. The lexis of a language is "the key to its history and culture" (Wierzbicka, 1999, p. 450) and "mirrors the world and faithfully reflects and records human perception of it" (Smółkowa, 2000, p. 58). Social, political, economic and cultural changes always find a reflection in language changes, most visible at the lexical level, which will be exemplified here with English domain-specific vocabulary that has enriched Polish lexis. It must be stressed that the English-Polish language contact in its 400-hundredyear-old history, summarised below, has been almost exclusively unidirectional. Section 2 offers an overview of domain-specific Anglicisms in Polish, with special emphasis on the semantic fields of leisure, fashion and entertainment, sketched against historical background.

\section{Polish Anglicisms in semantic fields - a historical overview}

It is useful to classify foreign loans thematically to single out the areas of life or semantic fields that, at a certain point in time, have expanded due to language contact. Foreign loans, apart from being of onomasiological value to the recipient language users, are evidence of cultural contacts between speech communities. Lexical borrowing mirrors contact-induced social, economic and cultural changes that the recipient language community experiences. "Cultural borrowings" are features borrowed from a different language which "show us what one nation has taught another". They are manifestations of "cultural diffusion", i.e. the "spread of things and habits" among nations. Cultural concepts derived from one language and culture cross boundaries to enrich other languages and cultures. "Along with objects or practices, the speech-forms by which these are named often pass from people to people" (Bloomfield, 1933, pp. 444-445, 458). The role of various communities in the development of civilisation can be estimated on the basis of language contacts and the adoption of lexical elements which transmit new ideas, names of inventions and discoveries, and cultural phenomena (Sapir, 1921). Foreign loans take part in the shaping of the recipient language just as foreign cultural elements influence and 
alter the recipient culture. The analysis of foreign loans shows which languages and cultures have been considered most attractive and prestigious by the recipient language users (Piotrowski, 2008, p. 376).

Before the $18^{\text {th }}$ century, English-Polish language contacts were only occasional and the Anglo-American culture was hardly known in Poland. Poles benefited culturally and linguistically from other cultures; contacts with the Czechs (pre-16 ${ }^{\text {th }} \mathrm{c}$.) and later with the Italians $\left(16^{\text {th }}\right.$ c.), the French $\left(19^{\text {th }}\right.$ c.) and Germans (throughout Poland's history) were very strong and always resulted in linguistic borrowing, present in Polish until today. Therefore the first Anglicisms in Polish, which were almost exclusively lexical loans, were culture-specific and referred predominantly to British, and later also to American, cultural phenomena. The first English words in Polish were geographical names, e.g. P. Anglia (Słownik Knapiusza, 1621), Mississippi (Słownik Trotza, 1779), as well as culture-specific terms denoting positions, titles and currency, e.g. the $17^{\text {th }}$-century P. lord, lord major, ${ }^{2}$ par, spiker ${ }^{3}$ (< E. speaker) ${ }^{4}$ (Merkuriusz Polski Ordynaryjny, the first Polish weekly published in 1661), the $18^{\text {th }}$-century P. wig, funt stirling (< E. pound sterling), dolar (< E. dollar) (Mańczak-Wohlfeld 2006, p. 18; 2010, p. 8).

The second half of the $18^{\text {th }}$ century brought the first Anglicisms related to the domains of leisure, fashion and entertainment, e.g. P. gril (<E. grill), jacht (< E. yacht), pic-nic (< E. picnic, MnP. ${ }^{5}$ piknik), poncha (< E. punch, MnP. poncz) (Słownik Trotza, 1779). At the beginning of the $19^{\text {th }}$ century, the first monolingual dictionary of Polish, Słownik Lindego (1807-1814), records, e.g. P. flanela (< E. flannel), foxal (< E. Vauxhall), frak (< E. frock), klub (< E. club), muchair (< E. mohair, MnP. moher).

The increase in the number of lexical loans from English in the $19^{\text {th }}$ century was caused by several historical factors: the British victory in the Napoleonic Wars in 1815, the heyday of the British Empire "over which the sun never set", the Industrial Revolution in Great Britain that provoked the need to introduce to Polish factories new, English terminology along with the introduction of new technologies and machinery. An important factor in the introduction of Anglicisms to Polish was the

2 'the mayor of London'.

3 'the presiding officer of a legislative assembly'; later adapted semantically in Polish to mean 'announcer'.

$4 \quad$ English etymons are provided in cases where the loan has been adapted graphically or morphologically.

$5 \mathrm{MnP}=$ Modern Polish 
"Anglo-mania", born in the Romanticism and manifested through the Polish fascination with the English literature and English fashion (Adam Mickiewicz, a 19 century Polish Romantic poet, learns English to be able to read Byron's poetry and to translate The Giaour into Polish; Hrabia, a character in Mickiewicz's Pan Tadeusz (1834) follows English customs and dress code). The economic success of the USA and the American ideals of personal freedom as well as the relative religious tolerance attracted Polish economic, religious and political immigrants since 1608 (Walczak, 1983, p. 123; Mańczak-Wohlfeld, 2006, pp. 10, 36; Witalisz, 2016, p. 29). The Polish immigration to the USA was especially intensive during three periods: at the turn of the $19^{\text {th }}$ century - political immigration, the turn of the $20^{\text {th }}$ century economic immigration, and post-World War II immigration that was both political and economic. Poles drew from the British and American lifestyles, and adopted British English and American English vocabulary that named new, unknown in this part of Europe, cultural patterns, sports, types of clothing, types of drink and food, and many other phenomena.

The semantic analysis of the lexical Anglicisms registered in the early $20^{\text {th }}$-century Słownik warszawski (SWar 1900-1927), carried out by Elżbieta Mańczak-Wohlfeld (1988, p. 28; 2006, p. 17ff), groups the 180 English-sourced lexemes into 18 semantic fields, of which the field of sports and games is most richly represented, e.g. P. finisz $(<\mathrm{E}$. finish), lider (< E. leader), rekord (< E. record), sport, start, tenis (< E. tennis), trener $(<$ E. trainer), which points to the Polish fascination with English sports. Other domains with a substantial number of English loanwords include: social and political life, economy, as well as food and drink, e.g. P. dżyn (< E. gin, MnP. gin), pikle (< E. pickle), sandwicz ( $<\mathrm{E}$. sandwich), whiskey, and clothes and types of cloth, e.g. makintosz (< E. mackintosh), smoking (<E. smoking jacket), welwet (<E. velvet). ${ }^{6}$

The continuously growing quantity and thematic diversity of lexical Anglicisms in Polish at the beginning of the $20^{\text {th }}$ century resulted in the first semantic analysis of the 531 English lexical loans collected by Halina Koneczna (1936-1937). Of the 21 semantic fields identified in Koneczna's study, the most richly represented are again the semantic fields of sports (121 items), and maritime navigation (100 items). Early $20^{\text {th }}$-century Anglicisms are also frequent in the areas of cultural life, trade, industry and banking, clothes and types of cloth, dances and games.

The steady growth in the number of lexical Anglicisms in $20^{\text {th }}$-century Polish was

What strikes is the degree of the graphic adaptation of these late $19^{\text {th }}$-century loans, which must have been directly related to the solicitude for the purity of Polish at the time of the annexation of Poland by her three neighbours (in the years 1793-1918). 
stimulated by diplomatic and political contacts with Great Britain and the United States, business exchange, development of sciences, new technologies, a continuous fascination with sports, and by the overpowering American popular culture. This brought about a further growth in the number and diversity of semantic fields that were enriched due to intensive English-Polish language contact, which found a reflection in a 1970 study by Jacek Fisiak, who analyses over 700 English lexical loans and proposes their division into 12 major semantic fields, each of which includes a more detailed segmentation into semantic subgroups. For instance the semantic field of sports, with the greatest number of lexical Anglicisms, has been subdivided into 12 categories, e.g. general sports terms, athletics, team games, tennis. English loans presented in Fisiak's study abound also in the fields of science and technology, food and drink, people and society, maritime navigation, economy and trade, as well as clothes, fashion, cosmetics and decorations, which illustrates which particular areas of Anglo-American culture were found attractive by Poles.

Hidden behind the Iron Curtain for over four decades in the second half of the $20^{\text {th }}$ century, Poles had very limited access to cultural novelties from Western Europe and the United States of America. Contacts with the West were maintained through the Polish diasporas settled mainly in the United States, but also in West European countries. The year 1989, a political and historical breakthrough in Poland ${ }^{7}$ and later also in the whole of Central and Eastern Europe, was the beginning of an uncritical adoption of Western, chiefly Anglo-American, concepts and values along with the English vocabulary for which Polish equivalents were not available. Poles as well as other East and Central European nations began to draw intensely from the achievements of Western civilisations, which also meant the adoption of foreign lexis that named cultural patterns and technological advances.

The growing semantic diversity of loans corresponding to the growing number of Anglicisms in Polish towards the end of the $20^{\text {th }}$ century is revealed in studies carried out by Elżbieta Mańczak-Wohlfeld in 1992 and 1995. The analyses are based on over 1,600 Anglicisms for which 42, and later 45 , semantic fields have been identified. The

7 Following the Martial Law introduced in Poland in 1981 to crush political opposition, the formation of the "Solidarność" trade union movement under the leadership of Lech Wałęsa, and a series of factory strikes throughout the 1980s, the year 1989 brought about the final abolition of communism and of the 44-year-long Soviet dominance over Poland, which became a free and democratic country. The political changes initiated in Poland resulted ultimately in the fall of the entire Eastern and Central European communist block (with the opening of the Berlin Wall in 1989 as a symbol of the change) and brought about the end of the Cold War in 1991, thus lifting the Iron Curtain that divided Europe throughout the major part of the second half of the $20^{\text {th }}$ century. 
studies give a full account of the scale of the various areas of life in which Anglicisms are used by Polish speakers, ranging from sports, clothes, fashion, and entertainment through business, trade, economy and technology to geology, agriculture and philosophy. The 1992 study for the first time registers the semantic fields of computers, meteorology and cybernetics (Mańczak-Wohlfeld, 1992, pp. 3142). Work, advertising and drugs are thematic areas added in a 1995 revision of the anglicised semantic fields (Mańczak-Wohlfeld, 1995, p. 73). ${ }^{8}$ Finally, it must be added that a certain number of Anglicisms are left out without assigning them to any specific semantic category since each of them represents a different thematic area.

The theory of semantic fields has also been applied in the semantic analyses of covert Anglicims. Semantic loans from English have been divided into 18 semantic fields, of which politics, business, economy and trade, as well as popular culture including the subfields of film, music, food and lifestyle, are most numerously represented (Witalisz, 2007a, p. 186-190, 214). Similarly, loan translations calqued from English are most frequent in the domains of business, economy and banking, journalism, computer terminology, politics and popular culture including music, film and entertainment. Altogether English loan translations in Polish represent 28 different semantic fields which have at least several representatives, as well as other semantic areas which have been enriched only with single instances of calque from English (Witalisz, 2015, pp. 226-229).

The $21^{\text {st }}$-century globalisation processes, the role of English as the world's lingua franca and no technological limitations in sharing information facilitate the spread of novelties along with their names, many of which originate in English-speaking countries, particularly in the USA. Cultural and economic opening up to the West means an unstoppable adoption of the Western, chiefly American, cultural patterns that have been identified in several studies (Mosiołek-Kłosińska, 2000; Ożóg, 2004; Witalisz, 2007b). The elements of Anglo-American culture and civilisation that seem to particularly appeal to Poles include: lifestyle, consumerism, success, individualism, high self-esteem and informality as key elements, working styles, competitiveness,

The 45 semantic labels identified by Mańczak-Wohlfeld include the following: sport, human being, clothes and fashion, music, food, biology, sea, technology, economy, transportation, written language, computers, politics, physics, chemistry, trade, medicine, military, film, mining industry and metallurgy, minerals, geology, radio and television, religion, art, agriculture and gardening, tourism, English law, electricity, measures, entertainment, photography, philosophy and other ideas, geography, types of accommodation, cards, writing and printing, money, meteorology, education, cybernetics, materials, work, advertising, drugs (Mańczak-Wohlfeld 1995, pp. 66-73). 
pragmatism and ways of making a career, the cult of youth, beauty and practising sports, new trends in journalism, advertising and political life, communication through social networks, as well as eating styles and popular culture. This finds a reflection in the thematic types of language elements borrowed from English.

\section{Polish Anglicisms in the fields of leisure, fashion and entertain- ment - an analysis of language data}

As pointed out in Section 2, in the semantic studies on Anglicisms the three general domains that are of interest here, i.e. fashion, leisure and entertainment, have always found their place. As for the number of lexical Anglicisms, the semantic field of sports and games retains the leading position in English-Polish language-contact studies carried out throughout the $20^{\text {th }}$ century (Koneczna, 1936-1937; Fisiak, 1970; Mańczak-Wohlfeld, 1992, pp. 31-42; 1995, p. 73). Language-contact scholars also list English loans related to entertainment (incl. theatre, film, dances and types of music, card games, travelling, social life), fashion, clothing and types of cloth, as well as cosmetics and ornaments. The analyses of loan translations and semantic loans from English show that the semantic fields in question are decidedly less numerously represented than in the case of lexical loans (Witalisz, 2007a, pp. 186190, 214; Witalisz, 2015, pp. 226-229). The reason for this, apart from the proportionally smaller number of loan translations and semantic loans of English origin in Polish, may be the time difference between the respective studies.

The present study is based on Anglicisms excerpted from the available lexicographic works that list attested English lexical loans (SZA M-W, Mańczak-Wohlfeld, 2010), semantic loans (Witalisz, 2007a), loan translations (Witalisz, 2015) and loanblends (Witalisz, 2016), as well as from research projects carried out by English Philology MA students, participants of English-Polish Language Contact seminars in the years 2008-2017. The research material presented in Appendix 1 excludes, for reasons of space, the subfield of video games, which is amply represented with English loans.

The English loans in Polish presented in Appendix 1 cover three main semantic fields, i.e. entertainment, leisure and fashion, and several thematic subfields, which have been shaped to reflect the collected data. The research material comprises 1,123 domain-specific loans from English, presented in Tables 1-3, and divided with respect to the type of Anglicism and the semantic field and subfield represented. Where necessary, English etymons are provided. The most numerously represented are lexical loans (LW, 77.1\%), with loan translations (LT, 12.6\%), semantic loans (SL, $6.8 \%$ ) and loanblends (LB, 3.5\%) constituting the minority, which corresponds to the general quantitative observations made for all attested English loans in Polish (cf. 
Witalisz, 2016, p. 168).

As for the grammatical category of loans, nouns are in the majority (93\% of all loans listed in Appendix 1), which proves the onomasiological needs of the recipient language users as well as corresponds to the general tendency in language contact to borrow nouns as names for objects and concepts. English nouns (in the form of simple words, derivatives, compounds and acronyms) are borrowed predominantly as lexical loans, most of which keep their original graphic and morphological form, and are adapted only at the phonological level, e.g. P. after party, bestseller, country, e-book, GPS, happening, highlighter, jazz, jet lag, outlet, patchwork, reality show, remake, sequel, T-shirt, trailer, VIP, windsurfing, walkman. It has been observed that recent English loans tend to keep their original graphic form due to a better English competence among Polish speakers. Some nominal lexical loans, however, undergo graphic and, less frequently, morphological adaptation, as in e.g. P. celebryta $(<\mathrm{E}$. celebrity), dżingiel (< E. jingle), jacht (< E. yacht), kowbojki (< E. cowboy boots), kraul (<E. crawl), limeryk (< E. limerick), relaks (< E. relaxation), skecz (< sketch), skrecz (< E. scratch), stringi (< E. G-string).

The category of nominal lexical loans includes borrowed acronyms with 24 items (2.1\% of all loans listed in Appendix 1), e.g. apex (<E. APEX, Advanced Purchase Excursion), CD, CD-ROM, DJ/didżej (<E. DJ), DVD, HD, laser, SPF (<E. SPF, Sun Protective Filter), widżej (< E. VJ, Video jockey), L, M, S, XL, XS, XXL. Less frequent are borrowed English blends (3 items, 0.3\%), e.g. fanzin (< E. fan (maga)zine), kamkorder (< E. cam(era) (re)corder), motel, and clipped forms including clipping compounds (7 items, 0.7\%), e.g. blog (< E. (we)blog), glam (< E. glam[orous]), hi-fi (< E. hi(gh)-fi[delity]), op-art $(<\mathrm{E}$. op [tical] art), prom (< E. prom[enade concert]), sitcom (< E. sit[uation] com[edy]).

English polymorphemic nouns are often borrowed as loan translations, which are more or less exact lexical and structural copies of foreign etymons, e.g. P. długa piłka (< E. long ball), gadajqce głowy (< E. talking heads), kultura popularna (< E. pop(ular) culture), opera mydlana (< E. soap opera), spodnie rurki ( $<$ E. [drain] pipe trousers), Tydzień mody (< E. Fashion Week), waga piórkowa (< E. featherweight), ziemniak kanapowy (< E. couch potato) and, less frequently, as loanblends (half-translations) of polymorphemic foreign models, e.g. P. biznes wiadomości (<E. business news), botki peep toe (< E. peep-toe shoes), e-książka (<E. e-book), knajping (<E. clubbing), party ogrodowe (<E. garden party), rock garażowy (<E. garage rock), tenis stołowy (<E. table tennis). Nominal semantic loans are native (or well-assimilated foreign, chiefly Latin or French in this case) nouns whose meanings have been extended as a result of the influence of a foreign language. English nominal semantic loans in the researched areas include the new senses of e.g.: P. album 'a set of songs on a CD' (< E. album), 
dieta 'the usual food and drink' (< E. diet), film 'a thin layer of a cosmetic' (< E. film), konferencja 'an association of teams' (< E. conference), nominacja 'the act of appointing a person or thing to an award' (<E. nomination), resort 'a holiday village' (<E. [holiday] resort), sezon 'series' (<E. season), warsztaty 'an educational seminar of people engaged in study on a creative project' (<E. workshop).

Adjectives and attributive expressions (58 items, 5.2\% of all loans listed in Appendix 1) include English lexical loans, e.g. P. all inclusive, baggy, blue, french (< E. French manicure), hot, live, light, last minute, nonajron (< E. non-iron), topless, vintage, which are almost equalled in number by adjectival semantic loans from English, e.g. P. zaawansowany 'highly developed and complex' (< E. advanced), agresywny 'energetic, effective, dynamic' (< E. aggressive), ekonomiczny 'inexpensive' (< E. economy [class]), ekskluzywny 'unavailable for most people due to price; of the highest quality; reserved for particular people' (<E. exclusive), bazowy 'referring to foundation on which other cosmetics are applied' ( $<\mathrm{E}$. foundation [cream]), lekki 'containing a small amount of a harmful ingredient' ( $<\mathrm{E}$. light), przyjazny 'without negative effect; harmless' ( $<$ E. friendly), z drugiej ręki (<E. second-hand [clothes, car]). Loan translated English adjectives and attributive expressions are scarce in the collected data, e.g. P. na żywo (< E. live [concert, music]), bez prądu (< E. unplugged), przeciwłupieżowy (< E. anti-dandruff), przeciwzmarszczkowy ( $<\mathrm{E}$. antiwrinkle). English adjectives borrowed as lexical loans often undergo morphological adaptation in Polish, which is necessitated by its high inflectionality. Native adjectival suffixes -owy and -ski are added to English adjectives to make them inflectable in Polish, e.g. P. casualowy ( $<\mathrm{E}$. casual), dizajnerski ( $<\mathrm{E}$. designer), outdoorowy ( $<$ E. outdoor), oversizowy ( $<\mathrm{E}$. oversize).

Borrowed verbs constitute a mere $2.1 \%$ (24 items) of the collected data. All English verbs borrowed in the form of lexical loans undergo morphological adaptation on entering Polish, which is, as in the case of many adjectives, required by the grammatical system of the recipient language. Native verbal suffixes -ować or -ać are automatically attached to English verbs, e.g. P. surfować (< E. to surf), trenować ( $<$ E. to train), bukować (< E. to book), stepować (< E. to step), zaczekować się (< E. to check in), upgradować (<E. to upgrade). Verbal loans are also found among semantic loans from English, such as e.g. P. korespondować 'to match up with something' $(<$ E. to correspond with), praktykować 'to do repeatedly in order to gain skill' (< E. to practise), aplikować 'to apply a cosmetic onto the skin' (< E. to apply), ćwierkać 'to post tweets on Twitter' (<E. to tweet), dawać kopa 'to give excitement, energy' (<E. to give a kick). English polymorphemic verbal expressions are rendered in Polish as loan translations, e.g. P. kupować z domu (<E. to shop from home), Jesz, ile możesz (< E. All you can eat [restaurant]), and as loanblends, e.g. P. surfować w sieci (<E. to surf the web/net), robić newsy (<E. to do the news), być na standbaju (<E. to be on standby 
[mode]).

Well-established English loans form derivatives in Polish, which are not included in the research material since they are secondarily created within the recipient language at the post-borrowing phase and so are not considered loans sensu stricto. Apart from the obvious cases of adjectival, adverbial and verbal derivatives formed from nominal lexical loans, such as e.g. adjectives: P. fairplayowy < fair play, jazzowy < jazz, liftingujqcy < lifting, sportowy < sport, surfingowy < surfing, verbs: P. dubbingować < dubbing, finiszować < finisz (< E. finish), jazzować < jazz, rapować < rap, etc., wordformation processes are also applicable to loan translations, e.g. P. kablówka < telewizja kablowa (<E. cable television), sieciówka < sklep sieciowy (<E. chain store), śniadaniówka < telewizja śniadaniowa (< E. breakfast television), and semantic loans, e.g. P. warsztatowy < warsztaty $(<$ E. workshop).

In a few cases two types of loan co-exist, as if the recipient language users tried to find a native-sounding replacement in the form of a loan translation for a foreignsounding lexical loan, e.g. P. economy class co-exists with its loan translated version klasa ekonomiczna, all inclusive with właczajace wszystko, sitcom with komedia sytuacyjna ( $<$ E. situation comedy). Lexical loans that exhibit spelling and/or pronunciation variants are infrequent in the collected data, e.g. P. dżinsy/jeansy (<E. jeans), kraul/crawl (< E. crawl), kanioning/canyoning (< E. canyoning).

Many of the lexical loans within the domains of leisure, fashion and entertainment have been well institutionalised within the Polish language and usage, e.g. P. sport, golf, jacht (< E. yacht), dancing, czarter (< E. charter), musical, spiker 'announcer' (<E. speaker), bestseller, and many other. Loan translations and semantic loans due to the native language material of which they are composed are not considered loans by an average speaker of Polish, e.g. P. waga ciężka (< E. heavyweight), sieć hoteli (< E. hotel chain), płyta długogrająca (< E. long-playing record), kino domowe (< E. home cinema/theater [system]), etc.

Some English loans in the areas of leisure, fashion and entertainment appear due to linguistic snobbery and fashion for Anglicisation, rather than due to an immediate onomasiological need. Yet, in the analysed material a vast majority of Anglicisms must be considered necessary loans, for which Polish equivalents are not to be found, e.g. P. weekend, pi(d)żama (< E. pyjamas), as well as most of the musical and sports terminology. Luxury loans that co-exist with native terms are not frequent and include for instance some verbs borrowed from English: P. bukować (< E. to book) (cf. P. rezerwować), wyczil(out)ować się (< E. to chill out) (cf. P. wyluzować się), upgradować (< E. to upgrade) (cf. P. podwyższyć standard), the latter though involving an English loanword standard. The reasons for the use of unnecessary loans, other 
than snobbery and fashion, are pragmatic and must be sought for in the willingness to attract people's attention. Merchants attract Polish customers with Englishsounding novelties (such as e.g. P. marynarka casualowa (<E. casual jacket), eyeliner, outlet, sale, slippersy (<E. slipper boots), news presenters draw viewers' and listeners' attention through the use of novel-sounding expressions (such as P. green room, newsroom, reality show, sequel, trailer), travel agents want Poles to zaczekować się (<E. to check in) in a resort ( $<\mathrm{E}$. resort) and wyczil(out)ować się ( $<\mathrm{E}$. to chill out) on a jacht czarterowy ( $<\mathrm{E}$. charter yacht). Even very conservative Poles from the region of Zakopane, southern Poland, interlard their highly distinct dialect with English loanwords and pseudo-Anglicisms, as in the early 2017 radio commercial avertising the attractiveness of the region: "Przyizdzojcie w Tatry! Momy tu skipass, snow park i [...] winter festival!" [a dialectal version of: 'Come to the Tatra Mountains! We have a skipass, snow park and [...] winter festival!'].

In studies on Anglicisms, we often come across the problem of etymology. For a number of lexical loans, English serves only as the historical source of borrowing, rather than the genetic source. For non-European loans, English becomes an intermediary language through which "exotic" loans enter European languages, e.g. P. mokasyn (< E. moccasin < Algon. mockasin, makisin), P. tomahawk (< E. tomahawk < Algon. tāmāhāk), P. liczi (< E. lychee < Chin. lìzhi), P. kajak (< E. kayak < Inuit and Yupik qajaq), P. jo-jo (< E. yo-yo < Filipino yo yo) (SZA M-W, FD). English also becomes the medium through which non-English vocabulary becomes popularised in other languages, e.g. spa 'a place providing therapeutic baths and beautifying treatment' < Spa 'a resort town in Belgium' (or an abbreviated form of Latin salus per aquam), Slow Food - a movement that originated in Italy.

\section{Conclusion}

It is important to note that Polish Anglicisms in the domains of fashion, leisure and entertainment presented in this study (1,123 attested lexemes and expressions), constitute a sizeable part (14\%) of the total number of Anglicisms attested in various sources (Witalisz, 2016, p. 168). This reflects the Polish fascination with the American popular culture, understood broadly to include various forms of entertainment, ways of spending free time, eating habits, care for looks, and American lifestyle in general. Anglicisms within the domains of leisure (50.6\%) and entertainment (35.9\%) far outnumber those in the field of fashion (13.5\%). The most numerously represented semantic subfields include music, sports, beautifying treatments and ways of spending free time. A vast majority of the loans (93\%) are nouns, which reflects the onomasiological function of the borrowing process and the naming 
needs of the recipient language users. Direct lexical borrowing of complete English lexemes is a preferred technique of introducing foreign vocabulary; covert loans constitute $22.9 \%$ of the analysed data. Although there is a tendency to keep the original graphic form of English lexical loans, most of them are adapted phonologically and morphologically to fit the Polish grammatical system.

Intensive lexical borrowing from English bears testimony to the increasing onomasiological needs of Poles, who willingly draw from the achievements of the Anglo-American culture in such domains as sports and popular culture in general. The increase in the number of Anglicisms in Polish goes hand in hand with the growing diversity of the semantic fields they represent, as well as with the changeable proportions of Anglicisms within particular fields. Domain-specific loans give evidence to the development of particular areas of life which become important for the recipient language community. The types of the semantic fields that have been identified for English loans in Polish over the last one hundred years coincide with the social, economic, political, and cultural changes that Poland has been experiencing, as well as with technological advances and scientific discoveries in the Western world. This is also evident in the domains of leisure, fashion and entertainment, which have been substantially enriched, or significantly expanded, due to cultural and linguistic contacts. Lexical borrowing is an easy and effective method of referring to the borrowed cultural phenomena and borrowing from a more advanced or dominant culture has been a pragmatic choice for the inhabitants of the east side of the former Iron Curtain.

\section{Article history}

Paper received: 1 March 2017

Paper received in revised form and accepted for publication: 30 May 2017

\section{About the author}

Alicja Witalisz, PhD, D.Litt. is a Professor of English Linguistics at the Institute of Modern Languages at the Pedagogical University of Krakow, Poland. Her field of research is language contact and its outcomes. She publishes on linguistic borrowing from English and covert loans are her special interest. She has authored numerous articles as well as three monographs on English linguistic 
influence on Polish, Anglosemantyzmy w języku polskim - ze słownikiem (English semantic loans in Polish - with a dictionary), 2007, English loan translations in Polish: Word-formation patterns, lexicalization, idiomaticity and institutionalization, 2015, Przewodnik po anglicyzmach w języku polskim (A guide to Anglicisms in Polish), 2016. She is a member of several Polish and international academic associations and serves as a journal reviewer and advisory board member. She lectures on English linguistics and runs English-Polish language contact seminars.

\section{References}

Bloomfield, L. (1933). Language. New York: Henry Holt.

Doroszewski, W. (1938). Język polski w Stanach Zjednoczonych A.P. Warszawa: Nakładem Towarzystwa Naukowego Warszawskiego.

Fisiak, J. (1961). Zapożyczenia angielskie w języku polskim: analiza interferencji leksykalnej. Unpublished PhD dissertation. University of Łódź.

Fisiak, J. (1970). The semantics of English loanwords in Polish. Studia Anglica Posnaniensia, 2, 41-49.

Koneczna, H. (1936-1937). Wyrazy angielskie w języku polskim. Poradnik Językowy, 9, 161170.

Mańczak-Wohlfeld, E. (1988). Anglicyzmy w Słowniku warszawskim. Język Polski, LXVIII(1), 24-29.

Mańczak-Wohlfeld, E. (1992). Analiza dekompozycyjna zapożyczeń angielskich wjęzyku polskim. Rozprawy Habilitacyjne 235, Kraków: Uniwersytet Jagielloński.

Mańczak-Wohlfeld, E. (1995). Tendencje rozwojowe współczesnych zapożyczeń angielskich w języku polskim. Kraków: Universitas.

Mańczak-Wohlfeld, E. (2006). Angielsko-polskie kontakty językowe. Kraków: Wydawnictwo Uniwersytetu Jagiellońskiego.

Mańczak-Wohlfeld, E. (2010). Słownik zapożyczeń angielskich w polszczyźnie. Warszawa: Wydawnictwo Naukowe PWN.

Mosiołek-Kłosińska, K. (2000). Polskie słownictwo okresu 1989-1999 na tle współczesnych zjawisk kulturowych. In J. Mazur (Ed.), Słownictwo współczesnej polszczyzny w okresie przemian (pp. 75-85). Lublin: Wydawnictwo Uniwersytetu Marii Curie-Skłodowskiej.

Otwinowska-Kasztelaniec, A. (2000). A study of the lexico-semantic and grammatical influence of English on the Polish of the younger generation of Poles. Warszawa: Dialog.

Ożóg, K. (2004). Polszczyzna przełomu XX i XXI wieku. Wybrane zagadnienia. Rzeszów: 
Otwarty Rozdział.

Piotrowski, T. (2008). Zapożyczenia leksykalne w języku polskim jako ślady relacji kulturowych. In S. Gajda (Ed.), Język polski w europejskiej przestrzeni kulturowo-językowej (pp. 375-399). Opole: Wydawnictwo Uniwersytetu Opolskiego.

Sapir, E. (1921). Language. An Introduction to the study of speech. New York: Harcourt.

Smółkowa, T. (2000). Leksyka w początkowym okresie przemian ustrojowych. Rodzaje zmian. In J. Mazur (Ed.), Słownictwo współczesnej polszczyzny w okresie przemian (pp. 51-58). Lublin: Wydawnictwo Uniwersytetu Marii Curie-Skłodowskiej.

Walczak, B. (1983). The earliest borrowings from English into Polish. Studia Anglica Posnaniensia, 16, 121-131.

Wierzbicka, A. (1999). Język-umyst-kultura. Warszawa: Wydawnictwo Naukowe PWN.

Witalisz, A. (2007a). Anglosemantyzmy w języku polskim - ze słownikiem. Kraków: Tertium.

Witalisz, A. (2007b). Anglosemantyzmy jako odzwierciedlenie amerykańskich wpływów kulturowych. In W. Chłopicki (Ed.), Komunikacja międzykulturowa: perspektywy badań interdyscyplinarnych, Język a komunikacja 19 (pp. 235-244). Kraków: Tertium.

Witalisz, A. (2015). English loan translations in Polish: word-formation patterns, lexicalization, idiomaticity and institutionalization. Frankfurt am Main: Peter Lang.

Witalisz, A. (2016). Przewodnik po anglicyzmach w języku polskim. Kraków: Towarzystwo Miłośników Języka Polskiego.

\section{Dictionaries}

FD - The Free Dictionary. <http://www.thefreedictionary.com/>.

Słownik Knapiusza - Thesaurus Polonolatinograecus seu Promptuarium linguae Latinae et Graecae Grzegorza Knapskiego. Kraków. 1621.

Słownik Lindego - Słownik języka polskiego S.B. Lindego. Warszawa. 1807-1814.

Słownik Trotza - Nowy dykcyonarz to iest Mownik polsko-niemiecko-francuski: z przydatkiem przysłów potocznych, przestrog gramatycznych, lekarskich, matematycznych, fortyfikacyynych, żeglaskich [!], łowczych i inszym naukom przyzwoitych wyrazów, przez Michała Abrahama Troca, warszawianina, Lipsk 17441747.

SWar - Słownik języka polskiego. Słownik warszawski. J. Karłowicz (Ed.). Warszawa. 19001927

SZA F - Słownik zapożyczeń angielskich w języku polskim. J. Fisiak (Ed.) (forthcoming). 
SZA M-W - Słownik zapożyczeń angielskich w języku polskim. E. Mańczak-Wohlfeld (Ed.).

Warszawa. 2010.

\section{Appendix 1}

\begin{tabular}{|c|c|c|}
\hline & & ENTERTAINMENT \\
\hline$M$ & $\begin{array}{c}\text { LW } \\
9\end{array}$ & 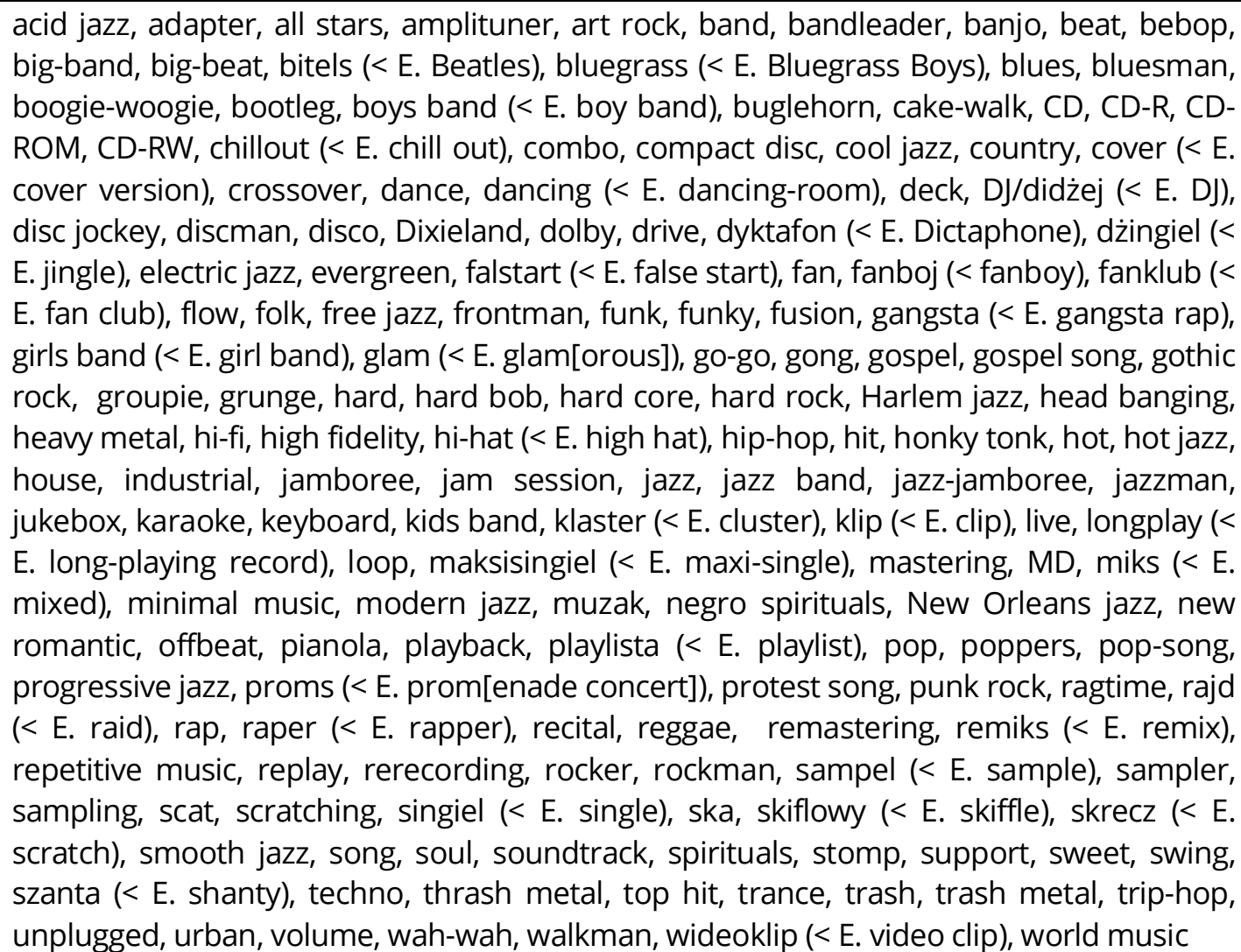 \\
\hline & LB & $\begin{array}{l}\text { rock garażowy (< E. garage rock), megaprzebój (< E. megahit), fanzlot (< E. fan meeting), } \\
\text { płyta kompaktowa (< E. compact disk) }\end{array}$ \\
\hline & LT & $\begin{array}{l}\text { piosenkopisarz (< E. songwriter), czarna muzyka (<E. black music), płyta długogrająca (< } \\
\text { E. long-playing record), album koncepcyjny (<E. concept album), kapela garażowa/zespół } \\
\text { garażowy }(<\text { E. garage band), przemysł muzyczny }(<\text { E. music industry), na żywo }(<\text { E. live } \\
\text { [concert, music]), wytwórnia płytowa (<E. record label), bez prądu (<E. unplugged) }\end{array}$ \\
\hline
\end{tabular}

LW - loanword (lexical loan), LB - loanblend, LT - loan translation, SL - semantic loan. 


\begin{tabular}{|c|c|c|}
\hline & SL & $\begin{array}{l}\text { album 'a set of songs on a CD' (<E. album), ekskluzywny 'available only for particular } \\
\text { people' (<E. exclusive), ikona 'a symbol' (<E. icon), kultowy 'significant for a particular } \\
\text { group of people' (< E. cult), nominacja 'the act of appointing a person or thing to an } \\
\text { award' (<E. nomination), nominować 'to appoint a person or thing to an award' (<E. to } \\
\text { nominate), nominowany 'one who has been nominated to an award' (< E. } \\
\text { nominated/nominee), pirat 'a person who illicitly uses or appropriates someone else's } \\
\text { literary, artistic, or other work' (<E. pirate), piractwo 'illicit use of someone else's literary, } \\
\text { artistic, or other work' (<E. piracy), sesja 'a meeting of a group of musicians to record in a } \\
\text { studio' (<E. session), zaawansowany 'highly developed and complex' (<E. advanced) }\end{array}$ \\
\hline \multirow[t]{4}{*}{$\begin{array}{l}\text { C } \\
\text { I } \\
\text { N } \\
\text { E } \\
\text { M } \\
\text { A } \\
\text { \& }\end{array}$} & LW & $\begin{array}{l}\text { blekaut (< E. blackout), blockbuster, blue box, blue movie, body shot, buddy movie, } \\
\text { casting, celebryta (<E. celebrity), cinerama, comeback, crazy comedy, dubbing, DVD, film, } \\
\text { gag, gagman, gore, HD, 3D, horse opera, insert, inset, kamkorder (<E. camcorder), klaps } \\
\text { (< E. clap), kowboj (< E. cowboy), light, love story, master, miks (<E. mixed), musical, } \\
\text { off(owy), off-Broadway, off-off-Broadway, Oskar (<E. Oscar), paintbox, prequel, remake, } \\
\text { science fiction, script, script girl, show business, sequel, slapstick, space opera, spaghetti } \\
\text { western, spotlight, starletka (<E. starlet), superstar, suspens (< E. suspense), Technicolor, } \\
\text { thriller, trailer, travelling, trik (<E. trick), trip, western, zombie, zoom }\end{array}$ \\
\hline & LB & $\begin{array}{l}\text { film akcji (<E. action film/movie), DVD premiera (<E. DVD premiere), nagrywarka DVD } \\
\text { (<E. DVD burner), film drogi (<E. road film/movie), film niezależny (<E. independent film), } \\
\text { video na życzenie (<E. video on demand) }\end{array}$ \\
\hline & LT & $\begin{array}{l}\text { czerwony dywan (<E. red carpet), końska opera (<E. horse opera), kosmiczna opera (<E. } \\
\text { space opera), Aleja sławy (<E. Walk of Fame), piętnaście minut sławy (<E. fifteen minutes } \\
\text { of fame), kino cyfrowe }(<\mathrm{E} \text {. d(igital) cinema), kino trójwymiarowe/kino 3D }(<\mathrm{E} \text {. three- } \\
\text { dimensional cinema/3D cinema), efekty dźwiękowe (<E. sound effects), gwiazda filmowa } \\
(<\mathrm{E} \text {. film/movie star), kino domowe }(<\mathrm{E} \text {. home cinema/theater [system]), przemysł } \\
\text { filmowy }(<\mathrm{E} \text {. film industry), ścieżka dźwiękowa }(<\mathrm{E} \text {. soundtrack), fabryka snów }(<\mathrm{E} \text {. } \\
\text { dream factory) }\end{array}$ \\
\hline & SL & $\begin{array}{l}\text { nominacja 'the act of appointing a person or thing to an award' ( }<\text { E. nomination), } \\
\text { nominować 'to appoint a person or thing to an award' }(<\mathrm{E} \text {. to nominate), nominowany } \\
\text { 'one who has been nominated to an award' }(<\text { E. nominated/nominee), obraz 'movie, film' } \\
\text { ( }<\text { E. picture), produkcja 'film, movie' ( }<\text { E. production), }\end{array}$ \\
\hline $\begin{array}{l}\mathbf{T} \\
\mathbf{V}\end{array}$ & LW & $\begin{array}{l}\text { anchorman, Big Brother, green room, greps (< AmE. grip), HDTV, interview, juror, mass } \\
\text { media, media planner, mikser (< E. mixer), miksować }(<\mathrm{E} \text {. to mix), multipleks }(<\mathrm{E} \text {. } \\
\text { multiplex), muppet, news, newsroom, (late) night show, no comment, number one, } \\
\text { power play, prime time, prompter, reality show, reality TV, reporter, sequel, serial, show, } \\
\text { showman, sitcom, soap opera, spiker (<E. speaker), spot, talk show, teaser, telerecording, } \\
\text { tranking (<E. trunking), TV, VCR, VHS, wideo (<E. video), widżej }(<\mathrm{E} . \mathrm{VJ}) \text { ), zapper, zapping }\end{array}$ \\
\hline $\begin{array}{l}\mathbf{R} \\
\mathbf{A} \\
\mathbf{D}\end{array}$ & LB & $\begin{array}{l}\text { webtelewizor (<E. webtelevision [set]), biznes wiadomości }(<\mathrm{E} \text {. business news), biznes } \\
\text { informacje }(<\mathrm{E} \text {. business information), robić newsy }(<\mathrm{E} \text {. to do the news), być na } \\
\text { standbaju (<E. to be on standby [mode]) }\end{array}$ \\
\hline $\begin{array}{l}1 \\
0\end{array}$ & LT & $\begin{array}{l}\text { srebrny ekran (<E. silver screen), gadające głowy (<E. talking heads), pilot programu }(<\mathrm{E} \text {. } \\
\text { pilot [TV] programme), radio konkurs (<E. radio competition), komedia sytuacyjna }(<\mathrm{E} \text {. } \\
\text { situation comedy), sukces medialny }(<\mathrm{E} \text {. medial success), opera mydlana }(<\mathrm{E} \text {. soap }\end{array}$ \\
\hline
\end{tabular}




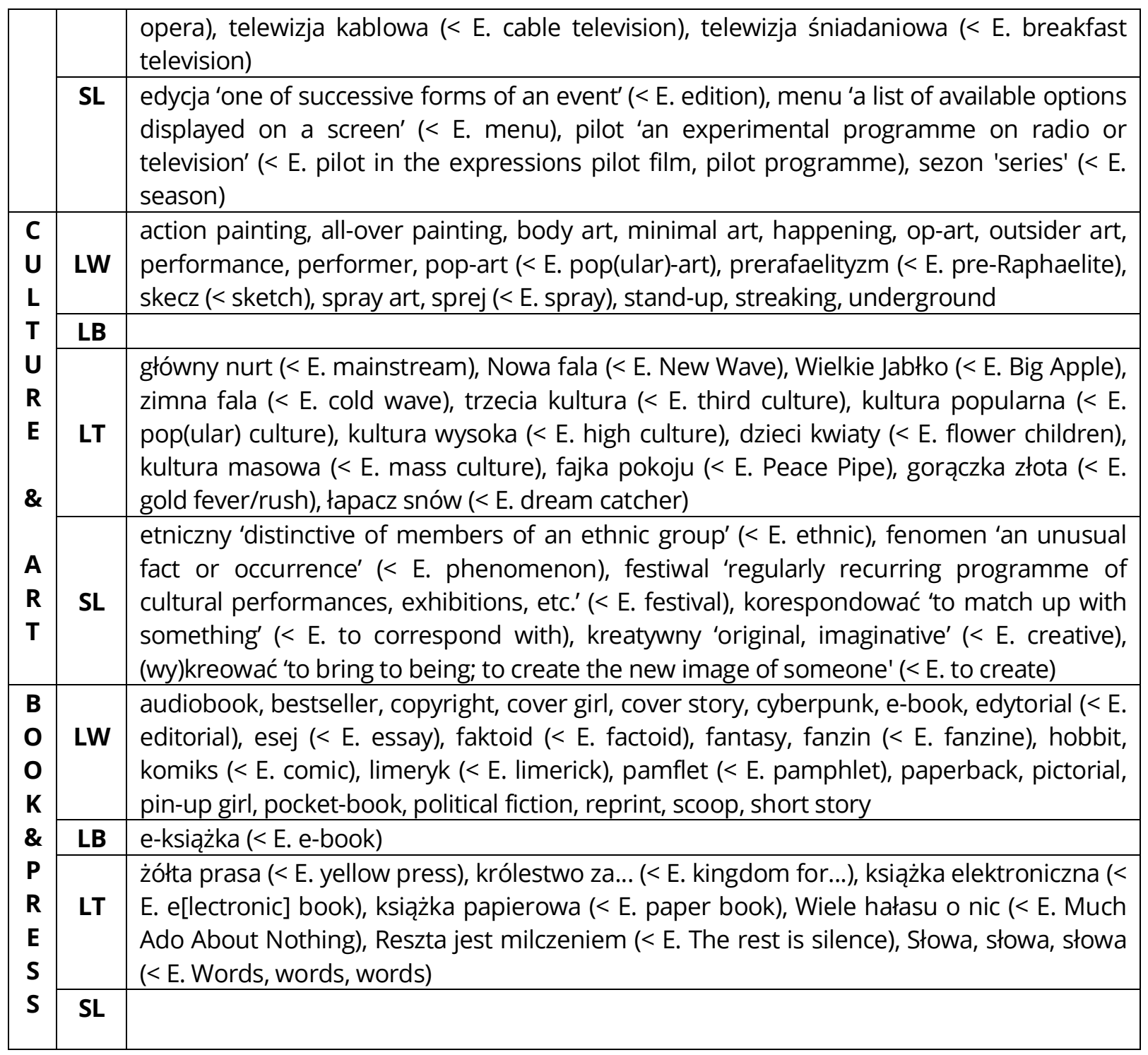

Table 1. Polish Anglicisms in the semantic field of entertainment. 


\begin{tabular}{|c|c|c|}
\hline & & LEISURE \\
\hline $\begin{array}{l}\text { S } \\
\mathbf{P} \\
\mathbf{O} \\
\mathrm{R} \\
\mathrm{T} \\
\mathrm{S}\end{array}$ & LW & 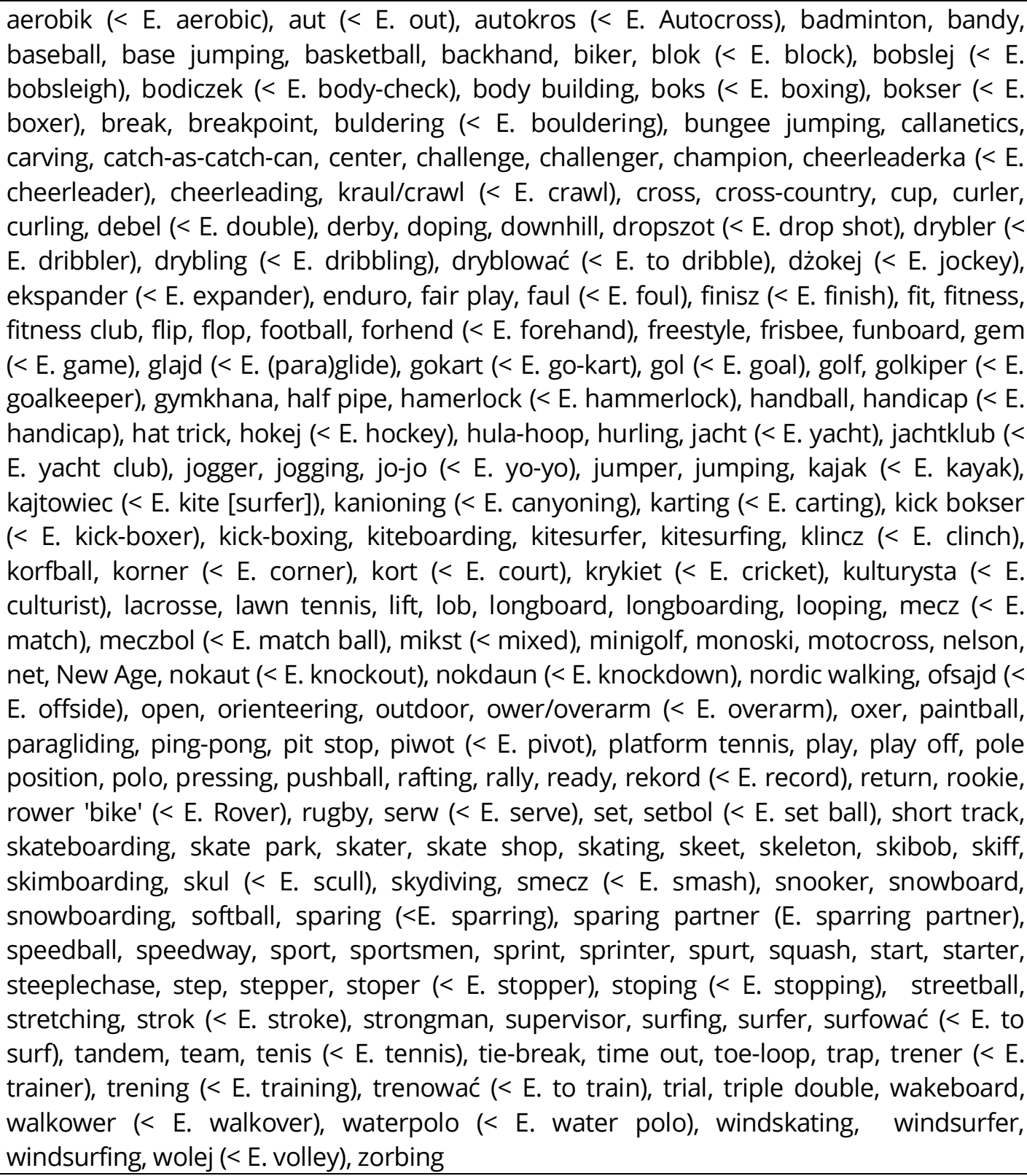 \\
\hline & LB & waga cruiser (< E. cruiserweight), tenis stołowy (<E. table tennis) \\
\hline & LT & $\begin{array}{l}\text { długa piłka (< E. long ball), półmostkowa [pozycja] (< E. semi-bridge [position]), } \\
\text { półłyżwowy (< E. semi-skating), sztuczna ściana wspinaczkowa (<E. artificial climbing } \\
\text { wall), slalom równoległy (<E. parallel slalom), slalom specjalny (<E. special slalom), waga } \\
\text { ciężka (< E. heavyweight), waga lekkociężka (< E. light heavyweight), bramka } \\
\text { kontaktowa/gol kontaktowy (<E. contact goal), narty wodne (<E. water skis), rower górski } \\
\text { (< E. mountain (terrain) bike), waga kogucia (< E. bantamweight), waga musza (< E. } \\
\text { flyweight), waga piórkowa (<E. featherweight), waga słomkowa (<E. strawweight), bieg }\end{array}$ \\
\hline
\end{tabular}




\begin{tabular}{|c|c|c|}
\hline & & $\begin{array}{l}\text { przez płotki (< E. hurdle race), liga mistrzów (< E. champions' league), spirala śmierci (<E. } \\
\text { death spiral) }\end{array}$ \\
\hline & SL & $\begin{array}{l}\text { agresywny 'energetic, effective, dynamic' }(<\mathrm{E} \text {. aggressive), egzekucja 'the performing, } \\
\text { realization of something' ( }<\text { E. execution), egzekutor 'one who performs an activity' }<\text { E. } \\
\text { executioner), konferencja 'an association of teams' (<E. conference), praktykować 'to do } \\
\text { repeatedly in order to gain skill' (<E. to practise), prezydent 'the chief executive officer of } \\
\text { a company' (<E. president) }\end{array}$ \\
\hline $\begin{array}{l}\text { T } \\
\text { R } \\
\text { A } \\
\text { V } \\
\text { E } \\
\text { L }\end{array}$ & LW & $\begin{array}{l}\text { all inclusive, apex (<E. Apex, Advanced Purchase Excursion), autocamping, bukować }(<\mathrm{E} \text {. } \\
\text { to book), camping, caravan, caravaning, cruise, cruising, czarter (<E. charter), economy } \\
\text { class, ekspres (< E. express train), first class, first minute, gate, globtroter (<E. globe } \\
\text { trotter), guide, hostel, interrail, jet, jet lag, kamper ( }<\text { E. camper), katamaran ( }<\text { E. } \\
\text { catamaran), last minute, last second, motel, overbooking, package tour, penthouse, room } \\
\text { service, steward, stewardessa (< E. stewardess), stop, terminal, tour operator, tramping, } \\
\text { traveller's cheque, trekking, upgradować (< E. to upgrade), voucher, work and travel, } \\
\text { zaczekować się (<E. to check in) }\end{array}$ \\
\hline $\mathbf{L}$ & LB & \\
\hline $\begin{array}{l}\mathbf{I} \\
\mathbf{N} \\
\mathbf{G}\end{array}$ & LT & $\begin{array}{l}\text { niski sezon }(<\mathrm{E} \text {. low season), wysoki sezon }(<\mathrm{E} \text {. high season), ostatnie wezwanie dla } \\
\text { pasażera }(<\mathrm{E} \text {. the last call for passenger), turystyka kosmiczna (<E. space tourism/travel), } \\
\text { na ostatnią sekundę }(<\mathrm{E} \text {. last second), hotel sieciowy }(<\mathrm{E} \text {. chain hotel), sieć hoteli }(<\mathrm{E} \text {. } \\
\text { hotel chain), z pierwszej chwili }(<\mathrm{E} \text {. first minute), z ostatniej chwili }(<\mathrm{E} \text {. last minute), }\end{array}$ \\
\hline & SL & $\begin{array}{l}\text { ekonomiczny 'inexpensive' (<E. economy), ekskluzywny 'unavailable for most people due } \\
\text { to price; expensive, of the highest quality' (<E. exclusive), karawan 'a dwelling place on } \\
\text { wheels' (<E. caravan), resort (<E. (holiday) resort) }\end{array}$ \\
\hline $\begin{array}{l}\text { D } \\
\text { A } \\
\text { N }\end{array}$ & LW & $\begin{array}{l}\text { b-boy, b-girl, breakdance, charleston, chippendales, fajf (< E. five o'clock), fokstrot (<E. } \\
\text { foxtrot), girlsa (< E. girl), go-go, hula, hully gully, jive, lambeth-walk, let's kiss, one-step, } \\
\text { pogo, quickstep, shimmy, stepować (<E. to step), swing, twist, two-step }\end{array}$ \\
\hline C & LB & \\
\hline $\mathbf{E}$ & LT & \\
\hline $\mathbf{S}$ & SL & \\
\hline $\begin{array}{l}\text { G } \\
\text { A } \\
\text { M }\end{array}$ & LW & $\begin{array}{l}\text { bingo, blackjack, blotka (<E. blot), brydż }(<\mathrm{E} \text {. bridge), dart }(<\mathrm{E} \text {. darts), dubleton }(<\mathrm{E} \text {. } \\
\text { doubleton), dżoker (<E. joker), flipper, forsing }(<\mathrm{E} \text {. forcing), ful }(<\mathrm{E} \text {. full house), krokiet }(< \\
\text { E. croquet), poker, puzle (< E. puzzle), quiz, relay, RPG, scrabble, strit }(<\mathrm{E} \text {. straight), } \\
\text { tangram, wist }\end{array}$ \\
\hline $\mathbf{E}$ & LB & \\
\hline $\mathbf{S}$ & LT & \\
\hline 10 & SL & Bingo! 'That's right!' (< E. Bingo!) \\
\hline & LW & $\begin{array}{l}\text { airbrush, bloker (blocker), blush, body painting, body wrapping, bronzer, brushing, cold } \\
\text { cream, conditioner, dezodorant (<E. deodorant), eyeliner, face lifting, fitness, french (E. } \\
\text { French manicure), highlighter, laser, layering, (face) lifting, liftować (<E. to lift), liposukcja }\end{array}$ \\
\hline
\end{tabular}




\begin{tabular}{|c|c|c|}
\hline $\begin{array}{l}\text { B } \\
\text { E }\end{array}$ & & $\begin{array}{l}\text { (< E. liposuction), lotion, make-up, peeling, piercing, rebid, SPF (Sun Protective Filter), } \\
\text { scrub, spray, szampon (<E. shampoo), tipsy (<E. tip), tonik (<E. tonic), wellness }\end{array}$ \\
\hline A & LB & farma urody/piękności (< E. beauty farm), bar tlenowy (<E. oxygen bar) \\
\hline $\begin{array}{l}\text { U } \\
\text { T } \\
\text { I } \\
\text { F } \\
\text { Y } \\
\text { I }\end{array}$ & LT & $\begin{array}{l}\text { przeciwłupieżowy (< E. anti-dandruff), przeciwzmarszczkowy }(<\text { E. antiwrinkle), } \\
\text { przydymione oczy/przydymiony makijaż }(<\text { E. smokey eyes/smokey (eye) make-up), } \\
\text { makijaż permanentny (<E. permanent make-up), mleczko kosmetyczne (<E. cosmetic } \\
\text { milk), odnowa biologiczna (<E. biological regeneration), uśmiech jak milion dolarów (< } \\
\text { E. a million-dollar smile), spalacz tłuszczu (<E. fat burner), odsysanie tłuszczu }(<\mathrm{E} \text {. } \\
\text { liposuction) }\end{array}$ \\
\hline $\begin{array}{l}\mathbf{N} \\
\mathbf{G}\end{array}$ & SL & 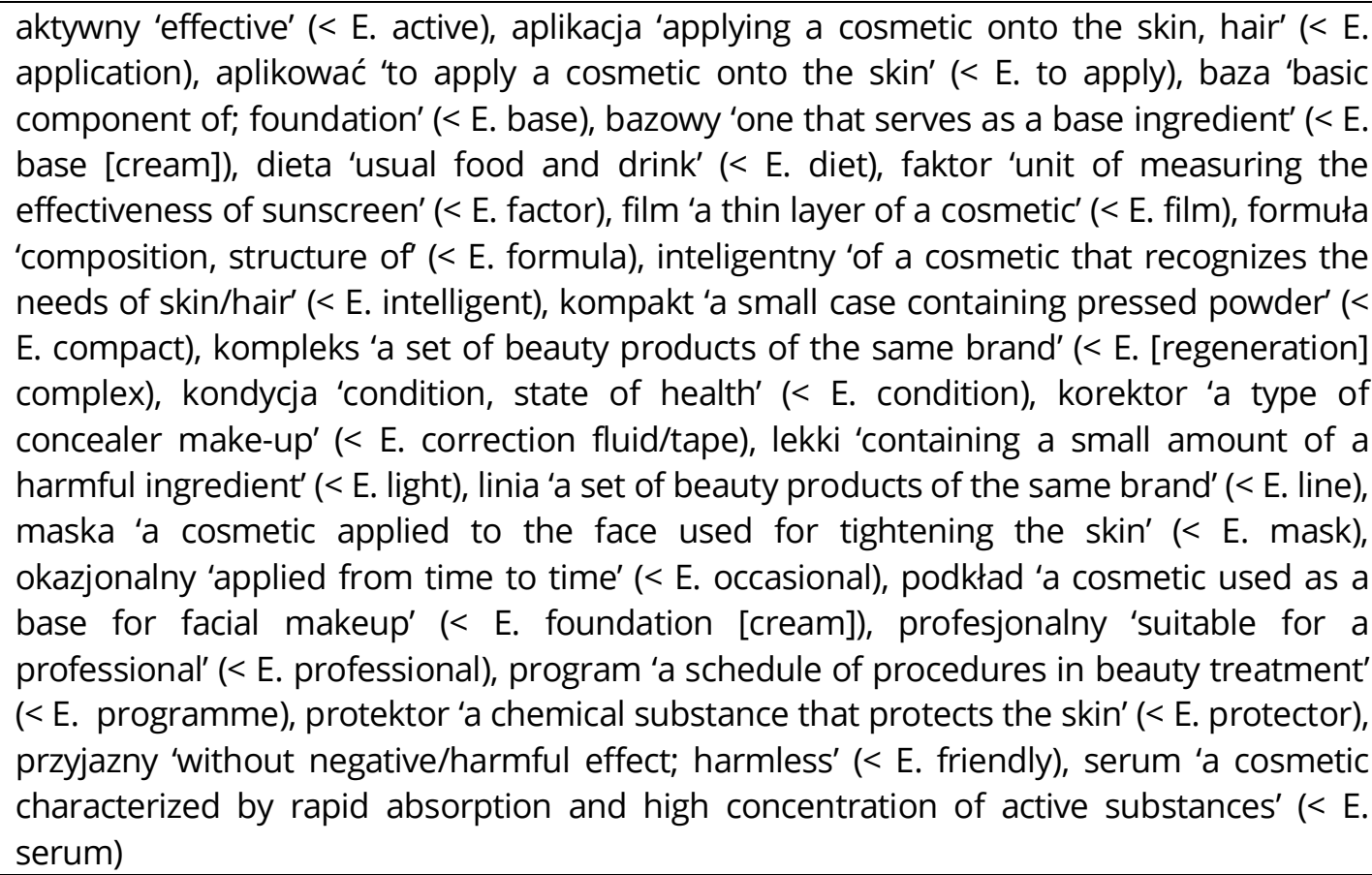 \\
\hline $\begin{array}{l}F \\
R \\
E \\
E\end{array}$ & LW & 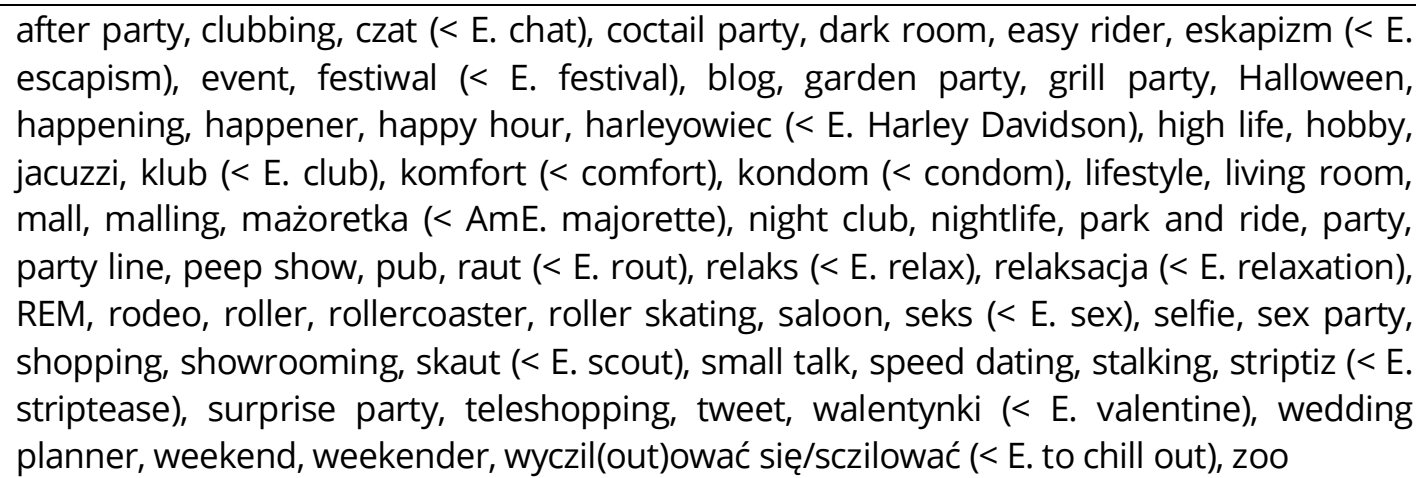 \\
\hline \& & LB & $\begin{array}{l}\text { pracoholic (<E. workaholic), lunch roboczy (<E. working lunch), bezpieczny seks (<E. safe } \\
\text { sex), zakuping (<E. shopping), knajping (<E. clubbing), sklepoholik/zakupoholik }(<\mathrm{E} \text {. } \\
\text { shopaholic), cyberlenistwo (<E. cyberslacking), cyberponiedziałek }(<\mathrm{E} \text {. Cyber Monday), } \\
\text { klub nocny ( }<\mathrm{E} \text {. night club), lunch biznesowy (<E. business lunch), ospa party }(<\mathrm{E} \text {. } \\
\text { [chicken]pox party), party ogrodowe (<E. garden party), surfować w sieci (<E. to surf the }\end{array}$ \\
\hline
\end{tabular}




\begin{tabular}{|c|c|c|}
\hline \multirow{3}{*}{$\begin{array}{l}\text { L } \\
\text { I } \\
F \\
E \\
S \\
T \\
Y \\
L \\
E \\
11\end{array}$} & & eb/net) \\
\hline & LT & $\begin{array}{l}\text { Czarny piątek (<E. Black Friday), plastikowe pieniądze (< E. plastic money), szczęśliwe } \\
\text { godziny }(<\mathrm{E} \text {. Happy hours), media społecznościowe (< E. social media), poczta } \\
\text { elektroniczna (< E. e[lectronic] mail), sieć społecznościowa (< E. social network), auto } \\
\text { rodzinne/samochód rodzinny (<E. family car), przyjęcie piżamowe/bal piżamowy (<E. } \\
\text { pyjama(s) party), wyprzedaż garażowa (< E. garage/yard sale), ziemniak kanapowy }(<\mathrm{E} \text {. } \\
\text { couch potato), strefa gier (< E. game zone), kupować z domu (<E. to shop from home), } \\
\text { Jesz ile możesz (<E. All you can eat [restaurant]), amerykański mit (<E. American dream), } \\
\text { Święto dziękczynienia (<E. Thanksgiving [Day]), }\end{array}$ \\
\hline & SL & $\begin{array}{l}\text { Ćwierkać 'to tweet on Twitter' (<E. to tweet), dawać kopa 'to give excitement, energy' (<E. } \\
\text { to give a kick), intymny 'referring to eroticism, sex' (<E. intimate), partner 'partner in a } \\
\text { relationship' (<E. partner), warsztaty 'an educational seminar of people engaged in study } \\
\text { on a creative project' (< E. workshop), ujawnienie się 'self-disclosing one's sexual } \\
\text { orientation' (<E. coming out [of the closet]) }\end{array}$ \\
\hline \multirow{3}{*}{$\begin{array}{l}\text { D } \\
\text { R } \\
\text { I } \\
\text { N } \\
\text { K } \\
12\end{array}$} & LW & $\begin{array}{l}\text { ale, apple pie, arak (<E. arrack), awokado (<E. avocado), bar, barbecue, bekon (<E. } \\
\text { bacon), Big Mac, Bloody Mary, brandy, brown sugar, brunch, burbon }(<\text { E. bour- } \\
\text { bon), burger, cafeteria, catering/katering, cheddar, cheeseburger, cherry, chester, } \\
\text { chipsy (<E. chips), chop suey, chowder, chutney, coca-cola, cocktail bar, cocktail } \\
\text { party, coffee-shop, colesław (< E. coleslaw), cornflakes, cumberland, curry, dip, } \\
\text { donut, dressing, drink, drink bar, drops, dżem (<E. jam), earl grey, energetyzer (< } \\
\text { E. energizer), energy drink, fast food, fingerfood (<E. finger food), fishburger, fru- } \\
\text { tarianin (<E. fruitarian), gin, golden delicious, graham (<E. Graham bread), grano- } \\
\text { la, grapefruit, grenadina (< E. grenadine), grill party, grog (< E. Old Grog), haggis, } \\
\text { halibut, hamburger, happy hours, hot dog, instant, Irish coffee, jonagold, jonatan } \\
\text { (<E. Jonathan [apple]), juice, junk food, kafeteria (<E. cafeteria), keczup (<E. ketch- } \\
\text { up), keks (<E. cake[s]), kipper (E. kipper), koktail/cocktail (<E. cocktail), krakers (<E. } \\
\text { cracker), kumin (<E. cumin), lancashire (cheese), light, liczi (E. lychee), long drink, } \\
\text { lunch, Mac, mango, melba, mufinka (< E. muffin), nugget, parkin, pekan, pemmi- } \\
\text { kan, pepermint (E. peppermint), pepsi-cola, pikle (E. pickle), piknik (< E. picnic), } \\
\text { poncz (< E. punch), popcorn, porter, pub, pudding, rostbef }(<\text { E. roast beef), rum, } \\
\text { sandwich, self-service, shaker, sherry, shot, slow food, snack bar, soft drink, stek (< } \\
\text { E. steak), stilton, stout, toffi (E. toffee), tost (<E. toast), whiskey }\end{array}$ \\
\hline & LB & $\begin{array}{l}\text { długi drink (<E. long drink), krótki drink (<E. short drink), krwawa Mary (<E. bloody } \\
\text { Mary), miękki drink (<E. soft drink) }\end{array}$ \\
\hline & LT & $\begin{array}{l}\text { beztłuszczowy (<E. fat-free), danie główne (<E. main course), głęboko mrożony (< } \\
\text { E. deep-frozen), Gorący Kubek 'Knorr's product' }<\text { E. Hot Cup), Jajko niespodzianka } \\
\text { (<E. [Kinder] Surprise Egg), Jasiu Wędrowniczek }(<\text { E. Johnnie Walker), Jesz, ile } \\
\text { możesz (<E. All you can eat [restaurant]), na lodzie (E. lit. 'on ice') }(<\text { E. on the }\end{array}$ \\
\hline
\end{tabular}

11 Excluding modern technologies and social networks.

12 Including meals, eating and drinking places and services, as well as eating and drinking styles. 


\begin{tabular}{|c|c|c|}
\hline & & $\begin{array}{l}\text { rocks), na skałach }(<\text { E. on the rocks), niskoprzetworzony }(<\text { E. low-processed), ni- } \\
\text { skotłuszczowy (<E. low-fat), płatki kukurydziane (E. cornflakes), restauracja siecio- } \\
\text { wa (E. lit. 'network restaurant') }(<\text { E. chain restaurant), sieć restauracji (E. lit. 'ne- } \\
\text { twork of restaurants') }(<\text { E. restaurant chain), szybkie jedzenie }(<\text { E. fast food), } \\
\text { śmieciowe jedzenie/śmieciowa żywność }(<\text { E. junk food), woda ognista }(<\text { E. fire } \\
\text { water), wolne jedzenie }(<\text { E. slow food), wysokoprzetworzony }(<\text { E. highly proces- } \\
\text { sed) }\end{array}$ \\
\hline & SL & $\begin{array}{l}\text { dieta 'usual food and drink' (< E. diet), lekki 'containing a small amount of fat' }(<\mathrm{E} \text {. } \\
\text { light), szef 'the chief cook of a large kitchen staff' (in this sense < E. chef) }\end{array}$ \\
\hline D & LW & $\begin{array}{l}\text { amfetamina (<E. amphetamine), blant (<E. blunt), crack, diler (<E. dealer), detoks } \\
\text { (<E. detox), drag (<E. drug), drag queen, dżoint }(<\mathrm{E} \text {. joint), ecstasy, gandzia (<E. } \\
\text { ganja }<\text { Hindi gãñã̃), grass, haj }(<\mathrm{E} . \text { high), hard, joint, LSD, speedball, spid (<E. } \\
\text { speed), spliff, staff }\end{array}$ \\
\hline $\mathbf{R}$ & LB & być/czuć się na haju (< E. to feel high) \\
\hline G & LT & $\begin{array}{l}\text { anielski pył 'type of drug, PCP' (< E. angel dust), baron narkotykowy (< E. drug } \\
\text { lord/baron), biała dama 'cocaine, heroin' (<E. white lady), biały proszek 'cocaine' (< } \\
\text { E. white powder), biała śmierć 'heroin' (< E. white death), być pozytywnym 'to be } \\
\text { infected with the HIV virus' (< E. to be positive), lekkie papierosy ( }<\text { E. light ciga- } \\
\text { rettes), miękki narkotyk (< E. soft drug), park igieł 'meeting place of drug addicts' (< } \\
\text { E. needle park), pigułka szczęścia (< E. happy pill), pył szczęścia 'cocaine, heroin; } \\
\text { drug in the form of powder' (<E. happy dust), twardy narkotyk (<E. hard drug) }\end{array}$ \\
\hline & SL & $\begin{array}{l}\text { przypudrować sobie nos 'to inhale a drug' (<E. to powder one's nose), szybka piłka } \\
\text { 'a mixture of cocaine and heroin' ( }<\text { E. speedball) }\end{array}$ \\
\hline
\end{tabular}

Table 2. Polish Anglicisms in the semantic field of leisure. 


\begin{tabular}{|c|c|c|}
\hline \multicolumn{3}{|c|}{ FASHION } \\
\hline \multirow[t]{4}{*}{$\begin{array}{l}\text { C } \\
L \\
O \\
T \\
H \\
E \\
S \\
\& \\
C \\
L \\
O \\
T \\
H \\
\& \\
S \\
H \\
O \\
E \\
S\end{array}$} & LW & 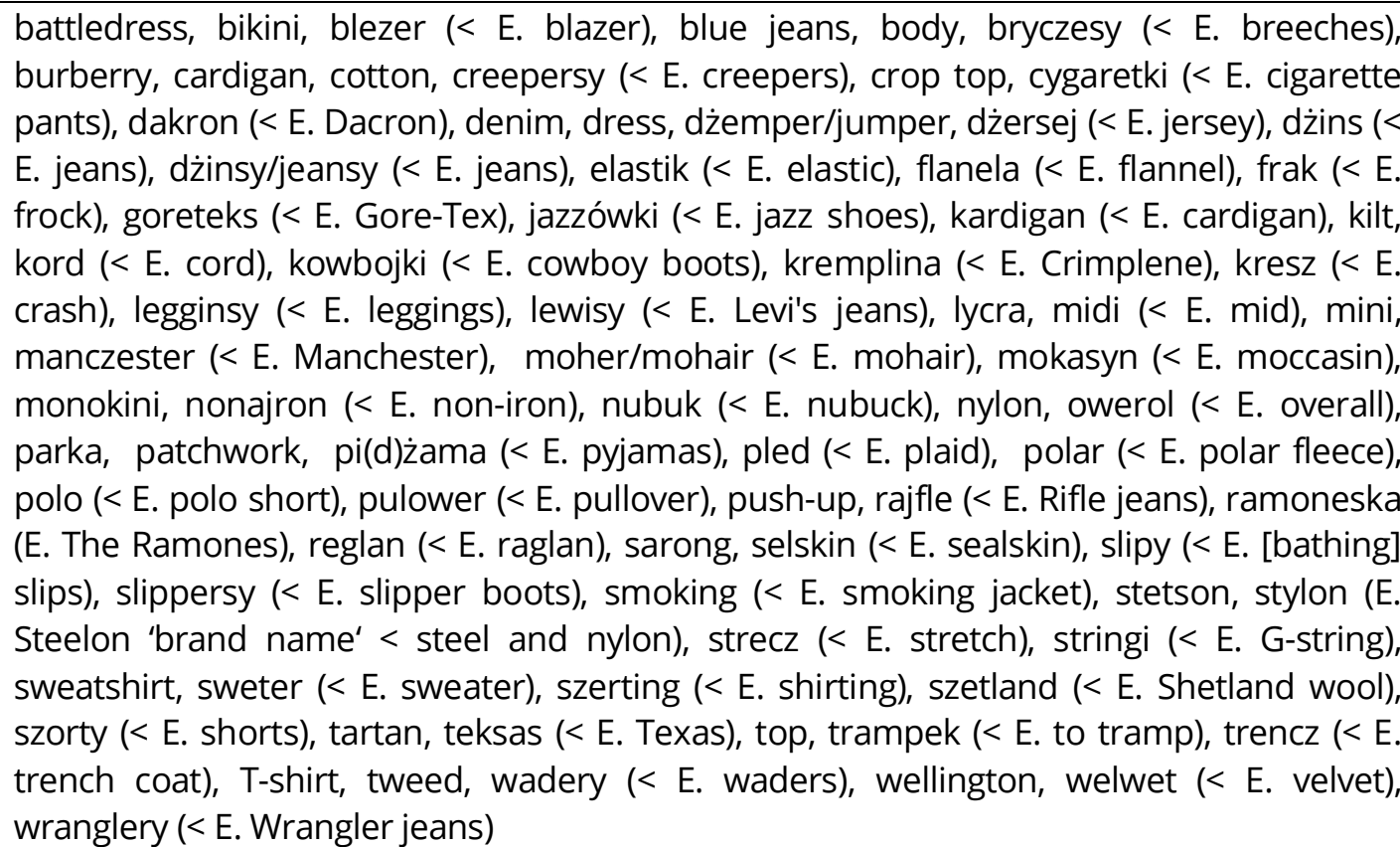 \\
\hline & LB & casualowa marynarka (<E. casual jacket), botki peep toe $(<$ E. peep \\
\hline & LT & $\begin{array}{l}\text { E. [drain] pipe trousers), wiatrówka (<E. } \\
\text { ) }\end{array}$ \\
\hline & SL & $\begin{array}{l}\text { etniczny 'distinctive of members of an ethnic group' (<E. ethnic), kreacja 'a garment for a } \\
\text { special occasion' (< E. fashion creation), kreator 'one who creates, originator' (<E. fashion } \\
\text { creator) }\end{array}$ \\
\hline \multirow[t]{4}{*}{$\begin{array}{l}\text { O } \\
T \\
H \\
E \\
R\end{array}$} & LW & 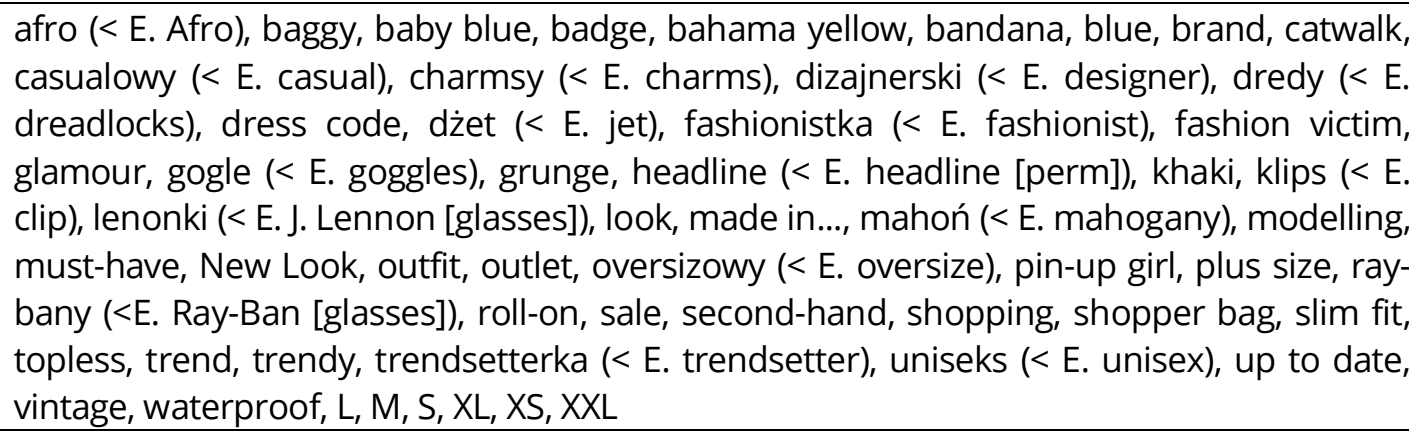 \\
\hline & LB & \\
\hline & LT & (a) \\
\hline & $\mathrm{S}$ & z drugiej ręki (< E. second-hand [clothes, car]) \\
\hline
\end{tabular}

Table 3. Polish Anglicisms in the semantic field of fashion. 